\title{
MANAGEMENT ACCOUNTING PRACTICES AMONG MALAYSIAN LOCAL GOVERNMENTS: AN EXPLORATORY STUDY
}

Che Ruhana Isa, Zakiah Saleh and Ruzita Jusoh ${ }^{1}$

\begin{abstract}
The main aim of this research is to review the frameworks currently developed and practiced in the public sector, in particular, the Malaysian local governments, and to identify the requirements for a better framework that can secure management control and facilitate accountability to users, the public and interested stakeholders. Specifically, this study investigates the management accounting and control practices, and the micro-accounting systems used by the local governments. It also examines the extent of the reforms or changes in these systems and the extent of micro-accounting implementation in these organisations. Among the management accounting practices, the results reveal that local government organizations are heavily involved with budgeting and performance measurement tools and show reasonable interest in accountability issues.
\end{abstract}

Keywords: Management Accounting Practices, Micro-accounting System (MAS), Local Governments

\section{Introduction}

Since the 1980s, there have been many changes in governments aimed at improving the efficiency of and effectiveness in the service delivery and the financial management of the organisations. Pollit and Bouckaert (2000) refer to the changes as 'public management reform', which they describe as "deliberate changes to the structures and processes of public sector organisations with the objective of getting them (in some sense) to perform better" (p. 17). According to

\footnotetext{
1 Corresponding author: Dr Ruzita Jusoh is an Associate Professor at the Faculty of Business \& Accountancy, University of Malaya, email: geee@um.edu.my. Dr Che Ruhana Isa and Dr Zakiah Saleh are also an Associate Professor at the Faculty of Business \& Accountancy, University of Malaya.
} 
Hood (1995, p. 93), public sector reform (PSR) is associated with the "doctrines of public accountability and organisational best practice" and has often been referred to as 'new public management' or 'new public financial management' (Lane, 1997; Heeks, 1998; Guthrie et al., 1999). Guthrie et al. (1999, p. 210) classified the new public financial management (NPFM) reforms into five categories - changes to financial reporting systems, development of commercially minded, market oriented management systems and structures, development of a performance measurement approach, devolvement or decentralisation or delegation of budgets, and changes to internal and external public sector audits. In essence, the categories identified by Guthrie et al. show that PSR has resulted in changing public sector accounting to be more in line with private sector accounting. The emphasis in accounting has shifted from showing stewardship and accountability to measuring performance and efficiency in the public sector. Management accounting and control systems also play an important role in the public sector, in monitoring governmental finances, distribution of resources according to the priority set by the government as well as ensuring the use of resources in an effective and efficient manner.

In the past two decades, the business environment has changed dramatically in which it is argued that the changes in organizations have been influenced by three factors - technological, organizational and personal perspectives (Linstone and Mitroff, 1994). Advancements in information technology and trade liberalization have significantly intensified competition, both in the domestic and the international markets (Atkinson et al., 1997). In responding to the escalating competition, private as well public sector organizations need to constantly review and revise their strategies to make themselves agile and responsive to market changes (Cooper, 1996). Organizations undertake structural changes, which include information and communication networks, such as Management Accounting and Control Systems (MACS), to achieve business performance targets (Williams \& Seaman, 2002). Since MACS play a vital role in monitoring the strategic progress of a firm through a feedback information system, it is imperative that organizations implement relevant changes in the system to ensure that the system continues to provide relevant and timely information to managers.

The public sector in Malaysia is established in accordance with the Constitution, in that the Government consists of three tiers: federal, state and local. The local government tier is established under the jurisdiction of the state government tier, and is often referred to as the local authority. It is divided into two groups: municipalities for large towns, and district councils for small urban centres. The functions of local authorities are concerned with the environment (including the provision of services, such as cleaning, collection, and disposal of waste, and sewerage system); public amenities; public health and cleaning (including licensing for hawkers and shops); social functions; and developmental functions (providing infrastructure and support facilities). Although a public sector 
entity traditionally exists to provide services to the general public, the recent PSR in Malaysia has seen the Government undertaking commercial activities as well as charging the public for the services. As the structure and activities of the public sector change, the administration and financial consequences become more complex. Given that PSR has resulted in a change to public sector accounting, bringing it more in line with private sector accounting, there is a need to study how the management accounting practices and systems of the private sector can be implemented in the public sector organisations. Thus, the specific objectives of this paper are:

1. To examine the extent of new management accounting practices among the Malaysian local governments.

2. To examine the extent of traditional management accounting practices among the Malaysian local governments.

3. To examine the extent of micro-accounting system (MAS) adoption among the Malaysian local governments.

The remainder of this paper is organised in the following manner. Section 2 provides the literature review concerning the changes and reforms occurring in the public sector. More specifically, the literature highlights the changes and reforms to the management accounting and control systems. Section 3 presents the methodology and description of the sample. The descriptive statistics and results of the empirical findings follow in Section 4. Finally, the discussion and conclusion are presented in Section 5.

\section{Literature Review}

\subsection{Changes in The Public Sector}

According to Lane (1997, p. 2) "the public sector reform (PSR) drive was initiated during the 1980s in the advanced capitalist democracies as a response to the public sector expansion process that had been such a dominant feature of the OECD countries after the Second World War". During that period, there was an increase in the size of the public sector, in which the public sector had grown from an average of below $25 \%$ to over $45 \%$ of GDP. The increase in size brought about questions concerning the performance of the sector. Lane acknowledged that the public sector performance problem called for reform strategies, and that those being adopted included deregulation, privatisation and marketisation (DPM). The DPM approach "argues that the public sector needs to be reformed in a fundamental fashion, touching all three fundamental government functions: allocation, redistribution and regulation" (Lane, 1997, p. 2). Meanwhile, in the UK, for example, public sector reforms are characterised by new institutions, new frameworks of accountability, new management systems and processes, and new accounting practices and procedures. A major implication of all reforms is 
the shift in emphasis from the traditional stewardship role of accounting to cost management (Jackson and Lapsley, 2003).

In addition, Denning (2000) links the advances in technology, apart from responding to political and fiscal pressures, to the reasons for reforms and identified re-engineering, downsizing, privatisation and efforts to deliver services efficiently as the consequences of reforms. Likewise, Hoque and Moll (2001, p. 305) state that "a range of social, economic and technological pressures are forcing governments to become more effective, efficient and accountable for the use of publicly generated funds".

\subsection{Public Sector Reforms in Malaysia}

As in other countries, the Malaysian public sector has also been undergoing reform. The emphasis of the reform, which started in the 1960s, was on the development of the economy and infrastructure. This was then followed in the 1980s by efforts to improve the work systems and procedures, which included the introduction of quality control circles and the privatisation policy. In the 1990s, public sector reform in Malaysia was directed towards achieving excellence and quality. The principle strategies include improving systems and work procedures, upgrading the use of information technology, and enhancing accountability and discipline (Hussain, 1998). In general, the changes in the structure and activities of the public sector have led to changes in the way the public sector is managed and the need to improve the performance, results and quality of the services.

Malaysia has been undergoing reforms since the 1960s. At that time, reforms were directed towards economic and rural development in order to promote growth. The emphasis on economic growth continued into the 1970s through the implementation of the New Economic Policy, which saw various socio-economic development, projects and infrastructure programmes being drawn up for the country. Following the Montgomery-Esman study in 1965, several institutions were established including the Public Service Department (PSD) in 1968; the National Institute of Public Administration (INTAN) in 1972 and the Malaysian Administrative Modernisation and Management Planning Unit (MAMPU) in 1977, to support planning and implementation (Hussain, 1998). These institutions provide public sector training policies and programmes, as well as administrative and personnel development.

Public administrative reforms in the Malaysian public service include changes in the systems and procedures, the introduction of new technology, inculcation of values and changes in attitude, and new management tools, such as total quality management (TQM) and quality control circles (QCC) (Hussain, 1998). The reforms started in 1989, when the Government launched a nationwide Excellent Work Culture Movement aimed at providing quality products and services, and focusing on meeting the requirements of the customers. 
Since the launch of the Excellent Work Culture Movement, a series of Development Administration Circulars (DAC) was introduced to implement administrative reforms. The DACs provide directives and guidelines on administrative improvement to all government agencies (Ahmad, 1997; MAMPU, 1998). Some examples include DAC No. 7 of 1991: Guidelines on Quality Control Circles (QCC) in the Public Service; DAC No. 12 of 1991: The Use of New Forms in the Management of Capital Assets, Inventories and Office Supplies; DAC No. 1 of 1992: Guide on Total Quality Management (TQM) in the Public Service; DAC No. 3 of 1992: Manual on Micro-accounting System; DAC No. 3 of 1993: Guidelines on Client's Charter; DAC No. 1 of 1996: Implementation of a Standard Computerised Accounting System in the Federal Statutory Bodies and DAC No. 2 of 1996: Guidelines for Implementing MS ISO 9000 in the Civil Service.

Clearly, the Malaysian Government has implemented the management approach used by the private sector in the public sector in which emphasis was placed on performance and results, as evidenced from the guidelines on quality control circles (QCC) and total quality management (TQM). In addition to office automation to increase productivity, the provision of service is also more customer-oriented.

\subsection{Change to Management Accounting and Control Systems (MACS) in The Malaysian Public Sector}

In the past two decades, the business environment has changed dramatically due to trade liberalization and advancements in manufacturing and information technologies. In order to remain competitive and survive, organizations need to be flexible and responsive to market changes, and to constantly review and revise their strategies (Yakou and Dorweiler, 1995; Mia and Clarke, 1999). It has been argued that management accounting needs to change in response to the changes in the business environment in order to meet new information requirements (Johnson \& Kaplan, 1987). Ahmed (2004, p. 227) explains that management accounting change can be seen as being "triggered by external and internal pressures on a firm (Amat, carmona \& Roberts, 1994; Baines \& Langfield-Smith, 2003; Cobb et al., 1995; Jazayeri \& Hopper, 1999; Ter Bogt \& Jan van Helden, 2000) and that the changes take place to cater for better information needs to survive in a competitive environment (Baines \& Langfield-Smith, 2003; Cobb et al., 1995)". Similarly, Wickramasinghe and Alawattage (2007) assert that the changes in management accounting reflect how the environmental factors shape the internal process within organizations. For example, a study by Baines and Langfield-Smith (2003) shows that greater emphasis on differentiation strategies drives many other organizational and management accounting changes, such as the greater use of advanced management accounting techniques and increased use of non-financial performance measures that are designed to support a customer focus. 
The change in MACS has played a central role in initiatives for the reform of the public sector, and, as such, is of particular interest to researchers, policymakers and practitioners (Lapsley and Wright, 2004). For example, a study by Perera et al. (2003) reveals that changes in terms of the introduction, abandonment, and reintroduction of transfer pricing in a government trading enterprise occur as it moves from a protected monopolistic status to commercialization. In tandem with the changes in the business environment, there have been increasing efforts to improve the service delivery by, and accountability of government bodies, and the emergence of a 'New Public Sector', which emphasizes "the increased significance of management over old-style public administration with its preoccupation with rules, procedures and bureaucracy", and greater emphasis on incentives, results, and customer service (Clarke and Lapsley, 2004, p.243). Economic advancements have also led to a higher level of awareness among the public concerning their rights, which has resulted in a higher demand for better service delivery and accountability from public sector organizations, including local governments. The local governments are more affected by these demands as they are 'closer' to the public at large. Since, the activities of local governments mirror private sector business activities, the information needs of the managers of local governments would also change. Hence, the management accounting systems used by local governments need to be modified to meet the new information needs of their managers.

According to Jackson and Lapsley (2003), the management accounting innovations in use in the public sector include costing, budgeting and performance measurement tools. Their study reveals that most of the innovations occur in the area of performance measurement with nearly all the public sector organisations using one or more techniques, such as key performance indicators and the balanced scorecard. They also discovered that the use of innovative techniques in performance measurement was high in local authorities and government agencies, but that the use of budgeting, such as zero-based budgeting (ZBB), was much lower. In addition, they found that costing techniques were the least used with the activity-based costing $(\mathrm{ABC})$ being the only technique that was commonly used across the public sector. As expected, the adoption of accounting innovations by the public sector is largely affected by government influence (Lapsley and Wright, 2004).

Malaysia has focused on management accounting initiatives for the development of governmental accounting. An early initiative was the reform of the budgeting process. Prior to 1968, Malaysia adopted a line item budget focusing on inputs. The system emphasised "control, conformity with rules, and the legality of expenditure" (Dean, 1989: p.43). In 1968, the public sector financial management underwent a major reform with the introduction of a new budgeting system called the Programme Performance Budgeting System (PPBS).

The PPBS was implemented in 1969 with a former controller of the United States General Services Administration acting as budget adviser. The system 
was envisaged to "help government administrators to think and plan in terms of programme objectives and the most efficient and economical way of attaining them [and] to establish budget priorities between competing programmes" (Dean, 1989, p.64). However, the success of the system was limited by the lack of skills in human resources, incompatibilities between accounting and budgeting systems, lack of management commitment and difficulties in determining programme structures and performance measurement (Dean, 1989).

In the 1980s, as a result of the problems associated with the PPBS, particularly those relating to the implementation of the performance measurement and programme evaluation, a Modified Budgeting System (MBS) was devised. The MBS was premised on the PPBS, with the main objective being to increase the efficiency in the financial management of the Government, and, specifically, to increase accountability among the controlling officers, and programme and activities managers. The controlling officers were given the authority to manage financial resources under the principle of 'let managers manage' (Malaysian Administration Modernisation and Management Planning Unit (MAMPU), 2000). The MBS was introduced on a pilot basis in 1990. The system was implemented in all Federal Agencies in five phases between 1992 and 1995. The implementation of the MBS was expedited when the government set up computer networking in 1994. The change in budgeting system required a change in information. In order to assess the cost-effectiveness of a programme under the MBS, full cost information was required. The introduction of the Micro-accounting System (MAS) in 1992, which is similar to activity-based-costing, supplemented the information produced by the cash-based accounting system for the MBS.

Financial management in the government includes planning processes, implementation and control concerning the use of assets and public financial resources. In an attempt to increase the efficiency in financial management, the Malaysian public service took the following steps (MAMPU, 2000):

a. Strengthened the implementation of the micro-accounting system

b. Strengthened the implementation of a standard computerised accounting system in statutory bodies

c. Ensured follow up actions on the Auditor General's Report

d. Improved the assets and stores supplies management systems'

As stated in its manual, the MAS was also introduced to enhance the financial management and performance of public sector organisations and was designed to 'facilitate the collection, processing and preparation of cost information; prepare information on cost efficiently and in a more flexible manner; produce reliable cost information and contribute to the optimisation of the use of resources.'

The emphasis by the Malaysian Government on management accounting is clearly stated in the manual of the MAS: 
'[MAS] is another step towards strengthening management accounting at the department level. Its implementation would further improve the strategic planning process and engender the optimal utilisation of resources. In general, the implementation of [MAS] would further enhance accountability in the Public Service'. (MAMPU, 2000)

\section{Research Method}

The data collection was conducted using a mail questionnaire survey targeting the accountants of the Malaysian local governments. The whole population of the 144 local governments was selected for the survey, which was undertaken between February and April 2010. For this study, the accountants are considered as the most appropriate respondents as they are more familiar with the issues under investigation. The names and designations of the respondents were obtained from the websites of the respective local authorities. Before mailing the questionnaire, telephone calls were made to the respective local authorities to confirm the name, designation and address of the respondents.

As the study focuses on management accounting techniques and practices, both traditional and new management accounting practices were included in the questionnaire. A list of management accounting practices were taken from Libby and Waterhouse (1996), and Hoque and Adams (2008). A list of 23 different management accounting systems was developed from an extensive review of the current management accounting literature including the CMA Handbook, CMA Magazine, Journal of Cost Management, Management Accounting and various management accounting textbooks. The respondents were asked to rate the extent of usage and usefulness of the 23 MACS on a scale of 1 (Low extent) to 5 (Great extent), and 1 (Least useful) to 5 (Very useful), respectively. The MACS were divided into five main subsystems: planning, controlling, costing, directing and decision-making.

In addition, questions relating to the micro-accounting system were also asked. The respondents were asked to state their opinion concerning the extent of use of both traditional and new management accounting practices in their organizations. The respondents were also required to state the level of usefulness of these management accounting practices for decision-making. As discussed earlier, the MAS can be considered as an attempt by the government to implement activity based costing. In order to examine the extent of the adoption of the MAS, additional questions were included in the instrument. The respondents were asked to indicate their awareness of the circular regarding the MAS issued by MAMPU and to state the stage of the implementation of the MAS. Additional questions about the potential motives for the adoption of the MAS and the reasons for not adopting the MAS were also included in the questionnaire. After three weeks of the first mailing, a total of 20 responses were received. To increase the response rate, follow-up telephone calls were made and a few respondents requested that the questionnaire be resent. Finally, within a period of one month, 35 additional responses were received, giving a total of 55 responses or a $38.2 \%$ response rate. 
Table 1: Demographic Profile of Respondents

\begin{tabular}{|c|c|c|c|}
\hline Background & Categories & $\mathbf{N}$ & $\%$ \\
\hline \multirow[t]{3}{*}{ Gender } & Male & 13 & 23.6 \\
\hline & Female & 40 & 72.7 \\
\hline & Missing & 2 & 3.6 \\
\hline \multirow[t]{2}{*}{ Ethnicity } & Malay & 50 & 94.3 \\
\hline & Other & 3 & 5.7 \\
\hline \multirow[t]{5}{*}{ Age } & Less than 25 years & 2 & 3.6 \\
\hline & $25-35$ years & 23 & 41.8 \\
\hline & $36-45$ years & 20 & 36.4 \\
\hline & $46-55$ years & 8 & 14.5 \\
\hline & Missing & 2 & 3.6 \\
\hline \multirow[t]{7}{*}{ Education } & High School & 2 & 3.6 \\
\hline & Diploma & 17 & 30.9 \\
\hline & Degree & 31 & 56.4 \\
\hline & Master degree or above & 1 & 1.8 \\
\hline & Professional qualification & 1 & 1.8 \\
\hline & Other & 1 & 1.8 \\
\hline & Missing & 2 & 3.6 \\
\hline \multirow{7}{*}{$\begin{array}{l}\text { Years of } \\
\text { experience }\end{array}$} & Less than 1 year & 1 & 1.8 \\
\hline & 1 to 5 years & 14 & 25.5 \\
\hline & 6 to 10 years & 21 & 38.2 \\
\hline & 11 to 15 years & 9 & 16.4 \\
\hline & 16 to 20 years & 3 & 5.5 \\
\hline & More than 20 years & 5 & 9.1 \\
\hline & Missing & 2 & 3.6 \\
\hline \multirow[t]{5}{*}{ Organization } & DBKL & 1 & 1.8 \\
\hline & City Council & 9 & $16 / 4$ \\
\hline & Municipal Council & 9 & 16.4 \\
\hline & District Council & 34 & 61.8 \\
\hline & Missing & 2 & 3.6 \\
\hline \multirow[t]{7}{*}{ Job position } & Assistant Accountant & 27 & 49.1 \\
\hline & Assistant Auditor & 1 & 1.8 \\
\hline & Accountant & 20 & 36.4 \\
\hline & Treasurer & 2 & 3.6 \\
\hline & Financial Controller & 1 & 1.8 \\
\hline & Other & 2 & 3.6 \\
\hline & Missing & 2 & 3.6 \\
\hline
\end{tabular}

The background of the respondents is summarized in Table 1. The majority of the respondents were either accountants or assistant accountants $(85.5 \%)$ with either the federal, state or local government. The respondents were relatively young as $81.8 \%$ were aged 45 and below and the majority $(96.4 \%)$ of had studied at least at the diploma level. More than half were female (72.7\%) and the majority $(94.3 \%)$ were of Malay ethnicity. 


\section{Results and Discussion}

\subsection{Management Accounting Practices}

Table 2 presents the extent of the traditional management accounting practices and their usefulness for decision-making. Among the planning systems, the results indicate that the most frequently used and most useful was budgeting

Table 2: Traditional Management Accounting Practices: Extent and Usefulness

\begin{tabular}{|c|c|c|c|c|}
\hline & \multicolumn{2}{|c|}{ Extent } & \multicolumn{2}{|c|}{ Usefulness } \\
\hline & SD & Mean & SD & mean \\
\hline \multicolumn{5}{|l|}{ a) Planning systems } \\
\hline Budgeting & 1.50 & 5.55 & 1.15 & 5.83 \\
\hline Operation planning (production) & 1.83 & 3.82 & 1.85 & 4.15 \\
\hline Capital budgeting & 1.74 & 4.08 & 1.54 & 4.43 \\
\hline Strategic planning & 1.63 & 4.75 & 1.57 & 5.19 \\
\hline Other planning system & 2.06 & 3.35 & 2.06 & 3.64 \\
\hline \multicolumn{5}{|l|}{ b) Controlling systems } \\
\hline $\begin{array}{l}\text { Individual or team-based performance } \\
\text { Measurement }\end{array}$ & 1.62 & 4.54 & 1.50 & 4.83 \\
\hline $\begin{array}{l}\text { Organisational performance } \\
\text { Measurement }\end{array}$ & 1.67 & 4.63 & 1.66 & 5.00 \\
\hline Measurement of performance in terms of quality & 1.57 & 4.50 & 1.83 & 5.10 \\
\hline $\begin{array}{l}\text { Measurement of performance in terms of customer } \\
\text { satisfaction. }\end{array}$ & 1.56 & 4.79 & 1.30 & 5.20 \\
\hline Other measures & 1.99 & 4.22 & 1.91 & 4.36 \\
\hline \multicolumn{5}{|l|}{ c) Costing Systems } \\
\hline Direct allocation of marketing costs & 1.81 & 3.12 & 1.90 & 3.61 \\
\hline Direct allocation of overhead & 2.06 & 3.71 & 1.90 & 4.00 \\
\hline Internal (dept. or divisional) product transfers & 1.91 & 3.38 & 1.93 & 3.74 \\
\hline Other costing systems & 2.27 & 3.33 & 2.24 & 4.00 \\
\hline \multicolumn{5}{|l|}{ d) Directing Systems } \\
\hline Reward systems-bonuses & 1.94 & 3.54 & 1.92 & 4.11 \\
\hline Reward systems-pay-for-performance plans & 1.97 & 3.11 & 2.11 & 3.69 \\
\hline Other reward systems & 2.08 & 2.79 & 2.41 & 3.27 \\
\hline \multicolumn{5}{|l|}{ e) Decision-making systems } \\
\hline Information reported more frequently & 1.55 & 4.96 & 1.56 & 5.23 \\
\hline Use of more non-financial measures & 1.51 & 4.54 & 1.52 & 4.72 \\
\hline Information reported more broadly & 1.46 & 4.52 & 1.48 & 4.77 \\
\hline Other changes to reporting systems & 1.77 & 4.29 & 1.70 & 4.56 \\
\hline $\begin{array}{l}\text { Other changes to systems that do not appear on } \\
\text { the list }\end{array}$ & 2.55 & 3.44 & 2.55 & 3.75 \\
\hline
\end{tabular}

Scale $=1$ (strongly disagree) to 5 (strongly agree) 
systems (mean=5.55, 5.83), followed by strategic planning (mean=4.75, 5.19). A similar result was found within the Malaysian manufacturing context in that budgeting or budgetary control had the highest increased usage among the manufacturing companies (Tuanmat \& Smith, 2011). In terms of controlling systems, the respondents perceived 'Measurement of performance in terms of customer satisfaction' (mean $=4.79,5.20$ ) as the most frequently used and most useful. The results indicate that customer satisfaction should be given more emphasis when it comes to delivering public services as it can capture the ability of the government agencies to provide quality products and services, and the effectiveness of delivery as well as its overall customer service.

On the other hand, the most commonly used and useful costing system was 'Direct allocation of overhead' costs (mean=3.71,4.0). The most frequently used and most useful directing system was 'Reward systems-bonuses' (mean=3.54, 4.11) while for the decision-making system, the respondents believed 'Information reported more frequently' (mean $=4.96,5.23$ ) to be the most frequently used as well as the most useful for decision-making purposes.

The new management accounting practices are displayed by Table 3. The three most frequently used were 'Accountability' (mean=5.31), 'Modified budgeting system' (mean=4.88), and 'Key performance indicators' (mean=4.85).

Table 3: New Management Accounting Practices: Extent and Usefulness

\begin{tabular}{|l|c|c|c|c|}
\hline \multicolumn{1}{c|}{} & \multicolumn{2}{c|}{ Extent } & \multicolumn{2}{c|}{ Usefulness } \\
\cline { 3 - 5 } \multicolumn{1}{c|}{} & SD & mean & SD & mean \\
\hline Modified Budgeting System & 1.81 & $\mathbf{4 . 8 8}$ & 1.70 & $\mathbf{5 . 0 0}$ \\
\hline Management Accounting System & 1.76 & 3.89 & 1.59 & 4.56 \\
\hline $\begin{array}{l}\text { Government Financial and Management } \\
\text { Accounting System }\end{array}$ & 1.95 & 4.11 & 1.73 & 4.37 \\
\hline Activity Based Costing & & & & \\
\hline Activity Based Management & 1.68 & 3.40 & 1.68 & 4.27 \\
\hline Benchmarking & 1.73 & 3.88 & 1.50 & 4.53 \\
\hline Process Reengineering & 1.57 & 4.33 & 1.38 & 4.54 \\
\hline Total Quality Management (TQM) & 1.68 & 3.57 & 1.57 & 3.89 \\
\hline Balanced Scorecard & 1.65 & 4.12 & 1.57 & 4.46 \\
\hline Six Sigma & 1.56 & 3.23 & 1.57 & 3.82 \\
\hline Key Performance Indicators & 1.65 & 2.74 & 1.71 & 3.26 \\
\hline Quality Control Circle & 1.35 & $\mathbf{4 . 8 5}$ & 1.29 & $\mathbf{5 . 2 9}$ \\
\hline Accountability & 1.73 & 3.61 & 1.84 & 4.09 \\
\hline Accrual budgeting & 1.45 & $\mathbf{5 . 3 1}$ & 1.32 & $\mathbf{5 . 5 5}$ \\
\hline
\end{tabular}

Scale $=1$ (strongly disagree) to 5 (strongly agree) 
The high use of key performance indicators is in line with the high use of performance measurement in terms of customer and quality, as shown in Table 2. This finding is consistent with the study by Jusoh et al. (2011). Conversely, the most useful for decision-making were 'Accountability' (mean=5.55), followed by 'Key performance indicators' (mean=5.29) and 'Modified budgeting system' (mean=5.00). The most infrequently used were 'six sigma' (mean=2.74) and 'balanced scorecard' (mean=3.23). The lower usage of balanced scorecard is consistent with the study by Jusoh et al. (2011) in which it shows that only $9.8 \%$ of the Malaysian government agencies have actually implemented the balanced scorecard. Consistent with the extent of implementation, the respondents perceived both 'six sigma' (mean=3.26) and 'balanced scorecard' (mean=3.82) as least useful. With respect to 'activity based costing' (mean=3.4) and 'activity based management' (mean=3.88), the results reveal that the levels of implementation are much lower than the respective level of perceived usefulness (mean $=4.27$ and 4.53 , respectively).

\subsection{Micro-Accounting Practices}

The Micro-accounting System (MAS) is a system developed based on the general principles of activity based costing. It was introduced by the Malaysian Government as part of its reform initiatives to improve the efficiency and effectiveness of the service delivery by its agencies. The MAS is not mandatory to the local governments but they are encouraged to use the system. In order to determine the extent of the implementation of the MAS among the local governments, in a separate section, the respondents were asked to indicate the MAS practices in their organisations.

Table 4 shows that $63.3 \%$ of the respondents stated that they were unaware of the circular by MAMPU on the MAS implementation while only three $(8.3 \%)$ of the local governments implemented the MAS. This indicates that an overwhelming majority of the local governments did not implement the MAS, and, in fact, more than half of the respondents were not even aware of its existence.

Table 4: MAS Awareness and Implementation

\begin{tabular}{l|c|c|}
\hline Awareness on the circular on MAS issued by MAMPU & N & \% \\
\hline Yes No & 18 & 36.7 \\
TOTAL & 31 & 63.3 \\
& 49 & 100 \\
\hline Implement MAS? & 3 & \\
Yes No & 33 & 8.30 \\
TOTAL & 36 & 100 \\
\hline
\end{tabular}


To probe further on the MAS implementation by the local governments, the respondents were asked to indicate the stage of implementation. The results shown in Table 5 indicate that only 10 of them indicated that the MAS has not been seriously considered in their organisations, suggesting that the majority of the local governments did give some consideration to the MAS. Six respondents stated that the MAS is being considered but has not been implemented yet while three revealed that the MAS was considered but was later rejected. The other 21 local governments indicated that the MAS was approved but implementation has either not yet begun (3), in process (4), abandoned prior to implementation (4), implemented and abandoned (2), implementation complete and in the process of gaining acceptance (2) and complete implementation and used in decisionmaking (3).

Table 5: MAS Stage of Implementation

\begin{tabular}{|c|l|r|}
\hline & Stage of MAS Implementation & N (\%) \\
\hline 1. & MAS/ABC has not been seriously considered & $10(18.2)$ \\
\hline 2. & $\begin{array}{l}\text { MAS/ABC is being considered and implementation is possible, but } \\
\text { implementation has not yet been approved }\end{array}$ & $6(10.9)$ \\
\hline 3. & $\begin{array}{l}\text { MAS/ABC has been considered (not implemented) and rejected as a } \\
\text { cost assignment method }\end{array}$ & $3(5.5)$ \\
\hline 4. & $\begin{array}{l}\text { Approval has been granted to implement MAS/ABC and allocate } \\
\text { the necessary resources but implementation has not yet begun }\end{array}$ & $3(5.5)$ \\
\hline 5. & $\begin{array}{l}\text { Implementation is in process: The MAS/ABC implementation team } \\
\text { is in the process of determining the project scope and objectives, } \\
\text { collecting data and/or analysing activities and cost drivers }\end{array}$ & 4 (7.3) \\
\hline 6. & $\begin{array}{l}\text { MAS/ABC was approved for implementation but abandoned prior } \\
\text { to implementation }\end{array}$ & $2(3.3)$ \\
\hline 7. & MAS/ABC was implemented but later abandoned \\
\hline 8. & $\begin{array}{l}\text { Implementation is complete and is in the process of gaining } \\
\text { acceptance }\end{array}$ & $2(3.6)$ \\
\hline 9. & $\begin{array}{l}\text { Implemented and generally accepted: MAS/ABC information is } \\
\text { commonly used by non-accounting staff for decision-making and/ } \\
\text { or cost management purposes. It is considered a normal part of the } \\
\text { information system }\end{array}$ & \\
\hline
\end{tabular}

Note: Responses are not mutually exclusive.

Table 6 reveals that most of the top three potential motives for MAS adoption are 'We wished to try a new accounting innovation' (mean=4.80), 'Advice from auditors and/or consultants' (mean=4.7), 'The changing cost structure created the need to replace the existing system' $($ mean $=4.4)$ and 'Pressure from government 
or other regulatory authorities' (mean=4.4). Conversely, the least cited motive is 'Our competitors were using MAS/ABC' (mean=2.5). The results suggest the main motivations for the local governments to implement MAS are the internal drive to implement a new method of accounting as well as advice from auditors. Since the majority of the local governments did not apply the MAS, it is not surprising that pressure from competitors was the least mentioned motive for MAS adoption.

Since the majority of the local governments did not implement the MAS, it would be interesting to explore their reasons for not adopting it. From Table 7, it can be seen that the three most frequently cited reasons are: 'We do not have the information technology software to support a MAS/ABC system (mean=4.85), 'Lack of relevant employee skills in designing and operating a MAS/ABC system' (mean=4.77) and 'We do not operate in a very competitive environment so a MAS/ABC system is not required' (mean=4.76). Consistent with the above discussion, the least frequently cited reasons for not adopting the MAS is 'Our competitors are not introducing MAS/ABC' (mean=3.84).

Table 6: Potential Motives for MAS Adoption

\begin{tabular}{|l|c|c|}
\hline Potential motive for adoption MAS & SD & mean \\
\hline $\begin{array}{l}\text { The existing costing system did not provide useful information to } \\
\text { management }\end{array}$ & 1.77 & 3.30 \\
\hline It was necessary to update the existing costing information system & 1.49 & 3.70 \\
\hline The existing costing system was not reliable & 1.70 & 2.71 \\
\hline $\begin{array}{l}\text { The changing manufacturing environment created the need to replace } \\
\text { the existing system }\end{array}$ & 1.62 & 3.20 \\
\hline $\begin{array}{l}\text { To be seen as having a sophisticated costing system that was } \\
\text { comparable with best practice }\end{array}$ & 2.25 & 4.20 \\
\hline $\begin{array}{l}\text { The changing competitive environment created the need to replace } \\
\text { the existing system }\end{array}$ & 1.69 & 4.20 \\
\hline $\begin{array}{l}\text { The changing cost structure created the need to replace the existing } \\
\text { system }\end{array}$ & 1.84 & $\mathbf{4 . 4 0}$ \\
\hline We wished to try a new accounting innovation & 2.09 & $\mathbf{4 . 8 0}$ \\
\hline Advice from auditors and/or consultants & 2.00 & $\mathbf{4 . 7 0}$ \\
\hline Pressure from Government or other regulatory authorities & 2.22 & $\mathbf{4 . 4 0}$ \\
\hline $\begin{array}{l}\text { Other units within the company had benefited from adopting MAS/ } \\
\text { ABC }\end{array}$ & 1.93 & 3.20 \\
\hline Our competitors were using MAS/ABC & 1.58 & 2.50 \\
\hline Advice from parent or headquarters & 2.41 & 3.30 \\
\hline
\end{tabular}

Scale $=1$ (strongly disagree) to 5 (strongly agree) 
Table 7: Reasons for Not Adopting the MAS

\begin{tabular}{|l|c|c|c|c|}
\hline Reason for not implementing MAS/ABC & min & max & SD & mean \\
\hline $\begin{array}{l}\text { The perceived benefits of MAS/ABC do not justify the } \\
\text { cost of implementing it }\end{array}$ & 1.00 & 7.00 & 1.48 & 3.92 \\
\hline The control of overheads is already adequate & 1.00 & 6.00 & 1.41 & 3.95 \\
\hline Most of the costs in our business unit are fixed & 1.00 & 7.00 & 1.56 & 4.11 \\
\hline Insufficient support from top management & 1.00 & 7.00 & 1.90 & 4.11 \\
\hline $\begin{array}{l}\text { Lack of individuals to act as champions to support the } \\
\text { introduction of MAS/ABC }\end{array}$ & 1.00 & 7.00 & 1.95 & 4.71 \\
\hline MAS/ABC systems are too complex & 1.00 & 7.00 & 1.58 & 4.29 \\
\hline $\begin{array}{l}\text { MAS/ABC is limited in its ability to explain cost } \\
\text { variability }\end{array}$ & 1.00 & 7.00 & 1.55 & 3.92 \\
\hline Our competitors are not introducing MAS/ABC & 1.00 & 7.00 & 1.75 & 3.84 \\
\hline $\begin{array}{l}\text { We do not have the information technology software to } \\
\text { support a MAS/ABC system }\end{array}$ & 1.00 & 7.00 & 1.82 & $\mathbf{4 . 8 5}$ \\
\hline $\begin{array}{l}\text { MAS/ABC is limited in its ability to assist in cost } \\
\text { control }\end{array}$ & 1.00 & 7.00 & 1.49 & 4.05 \\
\hline Lack of acceptance by my managers & 1.00 & 7.00 & 1.89 & 4.45 \\
\hline $\begin{array}{l}\text { Lack of relevant employee skills in designing and } \\
\text { operating a MAS/ABC system }\end{array}$ & 1.00 & 7.00 & 1.71 & $\mathbf{4 . 7 7}$ \\
\hline We are fully satisfied with our current costing system & 1.00 & 7.00 & 1.74 & 4.08 \\
\hline $\begin{array}{l}\text { MAS/ABC is limited in its ability to generate more } \\
\text { accurate costs for decision-making }\end{array}$ & 1.00 & 6.00 & 1.40 & 4.13 \\
\hline $\begin{array}{l}\text { Most products or services consume similar quantities of } \\
\text { resources so there is no need to implement a MAS/ABC } \\
\text { system }\end{array}$ & 1.00 & 7.00 & 1.46 & 4.16 \\
\hline Resistance to change by the accounting function & 1.00 & 7.00 & 1.50 & 4.11 \\
\hline $\begin{array}{l}\text { MAS/ABC has never been considered because most of } \\
\text { the accounting staff do not understand the concept }\end{array}$ & 1.00 & 7.00 & 1.89 & 4.65 \\
\hline $\begin{array}{l}\text { The relatively small size of our firm does not justify } \\
\text { implementing a MAS/ABC system }\end{array}$ & 1.00 & 7.00 & 1.63 & 4.35 \\
\hline $\begin{array}{l}\text { We do not operate in a very competitive environment so } \\
\text { a MAS/ABC system is not required }\end{array}$ & 1.00 & 7.00 & 1.71 & $\mathbf{4 . 7 6}$ \\
\hline
\end{tabular}

Scale $=1$ (strongly disagree) to 5 (strongly agree)

\section{Discussion and Conclusion}

The results reveal that the traditional budgeting system is the most frequently used management accounting practice among the Malaysian local governments. In addition, a new innovative budgeting system, such as the MBS, has also gained increasing importance in recent years. Interestingly, performance measurement tools, particularly the tool that measures customer satisfaction has gained a new importance among the local governments. This result is supported by the high 
extent of use of key performance indicators (KPIs), which is believed to focus greatly on customer satisfaction. This is in line with what Jackson and Lapsley (2003) found in their study in which KPIs are used by a very high percentage of public sector organizations in Scotland. Jackson and Lapsley (2003) also concluded that most of the management accounting innovations take place in the area of performance measurement.

With respect to costing, the use of a new costing technique, such as activity-based costing and activity based management, is slightly higher than the traditional costing system using the direct allocation of overheads. However, the use of new costing techniques ranks much lower than the budgeting and performance measurement tools. Surprisingly, accountability is perceived to be the most frequently used and useful by the majority of the local government accountants. This shows that there is awareness among the accountants about the importance of accountability in the public sector. In line with the reform agenda, besides being responsible for delivering services that meet the local needs, the authorities or managers of local governments should also be given greater freedom to manage their resources and be held accountable for their performance. To some extent, the high use of budgeting, such as the modified budgeting system (MBS), is a reflection of accountability being enforced among the Malaysian local governments. Therefore, it is evident from the findings that budget is an integral part of the accountability system in these organizations.

The findings of the study reveal a low level of awareness and implementation of the MAS among the Malaysian local governments. However, those who have not implemented the MAS did consider implementing the system but did not proceed due to various reasons including inadequate IT support, the relevant skills of the employees, and the lack of urgency to implement the MAS. In addition, other reasons cited for low implementation are lack of a champion, lack of knowledge among staff, and lack of acceptance by managers. The results imply that the successful implementation of any change initiatives, such as the MAS, require the strong support of the employees and an adequate infrastructure. Furthermore, as suggested by Armenakis et al. (2007), the effective flow of change messages is pivotal for the successful implementation of change. Thus, inputs from various government agencies must be sought and an adequate due process must be in place to seek the views of the various stakeholders about the change programmes, such as the MAS. This initiative will improve the acceptance and understanding about the change programme, thus leading to a higher commitment towards the change programme. For example, a study by Isa et al. (2011) found that communication flow and change messages are significantly related to the commitment to change.

The findings provide several implications to the theory and practice. As the main role of a management accounting system is to provide useful information to help managers make effective decisions, the findings suggest that, to some extent, Malaysian local governments are required to use a new management 
accounting system or practice to support the decision-making needs of their managers or accountants within the changing public sector environment. The findings are also important for the public sector agencies to understand the reasons why a particular management accounting practice is or is not adopted. From a theoretical perspective, the study contributes significantly to the literature as it gives additional empirical evidence concerning the extent of the use of traditional and new management accounting practices within the context of the governmental agencies.

This study only focuses on the local governments, and, as such, the findings do not constitute a representative study of the entire public sector. In addition, this study is subjected to the usual limitations of cross-sectional survey research and non-random sampling. In order to obtain a better understanding of management accounting change in the local government, future research could employ a qualitative research approach, such as case study and in-depth interviews.

\section{References}

Ahmad, Mazlan (Dato' Paduka) (1997). Improving Public Service in Malaysia [WWW] <URL: http://www.psmpc.gov.au/media/sessionh2.htm> [accessed 27 December 1999].

Anthony, R.N, Dearden, J. \& Bedford, N.M. (1989). Management Control Systems, Irwin, Homewood: IL.

Arnaboldi, M. \& Azzone, G. (2005). Performance measurement and change: the case of Italian new public administration. International Journal of Business Performance Management, 7 (1), p. 1-1.

Armenakis, A.A., Berneth, J.B., Pitts, J.P., \& Walker, H.J. (2007). Organizational change recipients' belief scale: Development of an assessment instrument. Journal of Applied Behavioral Science, 43(4), 481-505.

Atkinson, A., Balakrishnan, R., Booth, P., Cote, J., Groot, T., Malmi, T., Roberts, H. Uliana, E. and Wu, A. (1997). New directions in management accounting research. Journal of Management Accounting Research, 9, 79-108.

Burchell, S., Clubb, C. Hopwood, A.G., Hughes, J. and Nahapiet, J., (1980). The role of accounting in organizations and society. Accounting, Organizations and Society, 5.

Burns, J. and Vaivio, J. (2001). Management accounting change. Management Accounting Research, 12, 389-402.

Chenhall, R.H. (2005). Integrative strategic performance measurement system, strategic alignment of manufacturing, learning and strategic outcomes: an exploratory study. Accounting, Organization and Society, 30, pp. 395-422.

Dean, P.N. (1989). Government Budgeting in Developing Countries. London: Routledge.

Denning, M.J. (2000). Governments Are Different. CAMagazine, December, Canadian Institute of Chartered Accountants, pp. 32-34. 
Guthrie, J., Olson, O. and Humphrey, C. (1999). Debating Developments in the New Public Financial Management: The Limits of Global Theorising and Some New Ways Forward. Financial Accountability \& Management, 15(3) \& (4), August/November, pp. 209-228.

Heeks, R. (1998). Information Systems and Public Sector Accountability. Working Paper Series, Paper No. 1. Institute for Development Policy and Management, University of Manchester.

Hood, C. (1995). The "New Public Management" in the 1980s: Variations on a Theme. Accounting, Organisations and Society, Vol. 20, No. 2/3, pp. 93-109.

Hoque, Z. and Adams, C. (2008). Measuring public sector performance. A study of Australian government departments. Research summary is available online at: http://www.cpaaustralia.com.au/cps/rde/xbcr/SID-3F57FECBC5784B9E/cpa/measuring_public_sector_performance_200808.PDF

Hoque, Z. and Moll, J. (2001). Public Sector Reform: Implications for Accounting, Accountability and Performance of State-Owned Entities - An Australian Perspective. The International Journal of Public Sector Management, Vol. 14, No. 4, pp. 304-326.

Hussain, Z.A. (1998). Responding to Citizens. Paper presented at the Workshop on Public Management in Support of Social and Economic Objectives, OECD, Paris.

Isa, C.R., Saleh, Z. and Jusoh, R. (2011). Commitment to change among government accountants in Malaysia. Asian Journal of Business and Accounting, 4(2), pp. 71-92.

Jackson, A., Lapsley, I. (2003). The diffusion of accounting practices in the new "managerial" public sector. International Journal Public Sector Management. Vol. 16, No. 5, 359-372.

Jusoh, R., Hartono, R. and Abu Hassan, H. (2011). Performance Measurement in Malaysian Public Sectors: An Exploratory Study. IPN Journal of Research and Practice in Public Sector Accounting and Management. Vol. 1. 87-119.

Lane, Jan-Erik (1997). Public Sector Reform: Only Deregulation, Privatisation and Marketization? In: Lane, Jan-Erik (ed.) Public Sector Reform: Rationale, Trends and Problems. London: Sage, pp. 1-16.

Libby, T. and Waterhouse, J.H. (1996). Predicting change in management accounting systems. Journal of Management Accounting Research, 8, 137-150.

Lapsley, I. and Wright, E. (2004). The diffusion of management accounting innovations in the public sector: a research agenda. Management Accounting Research, 15, 355-374.

MAMPU (1998). ISO 9000 in the Public Service of Malaysia. Forum ISO 9000 Perkhidmatan Awam, No. 1, Mac. [WWW] <URL: http:// www.mampu. gov.au/Publications/BuletinISO/1998/main.htm> [accessed 12 February 2002] 
(2000). The Civil Service of Malaysia: Moving Into The New Millennium. Kuala Lumpur: MAMPU.

Perera, S., McKinnon, J.L. \& Harrison, G.L. (2003). Diffusion of transfer pricing innovation in the context of commercialization: a longitudinal case study of a government trading enterprise. Management Accounting Research, 14(2), p. 140-164.

Pollit, C. and Bouckaert, G. (2000). Public Management Reform: A Comparative Analysis. Oxford: Oxford University Press.

Sharma, B. \& Wanna, J. (2005). Performance measures, measurement and reporting in government organizations. International Journal of Business Performance Management, 7 (3), p. 1-1.

Sven, M. (1996). Management accounting and control in services: structural and behavioural perspectives. International Journal of Service Industry Management, 7 (2), pg. 57.

Tuanmat, T.Z. \& Smith, M. (2011). Changes in management accounting practices in Malaysia, Asian Review of Accounting, 19(3), pp. 221-242.

Wickramasinghe, D. \& Alawattage, C. (2007). Management Accounting Change: Approaches and Perspectives, Routledge, Taylor and Francis Group, London and New York, NY.

Williams, J.J. and Seaman, A.E. (2001). Predicting change in management accounting systems: national culture and industry effects. Accounting, Organizations and Society, 26, 443-460.

Williams, J.J. and Seaman, A.E. (2002). Management accounting systems change and departmental performance: the influence of managerial information and task uncertainty. Accounting, Organizations and Society, 13, 419-445.

Wwita, J.I. (2000). Performance management model: A systems-based approach to public service quality. The International Journal of Public Sector Management, 13 (1), pp. 19-37. 